\title{
Penyesuaian Dosis Obat pada Pasien Gagal Ginjal Kronis Rawat Inap di Rumah Sakit Kabupaten Tegal, Indonesia
}

\author{
Drug Dose Adjustment in Hozpitalized Patients with Chronic Kidney Disease \\ in Tegal Distric Hospital, Indonesia
}

\author{
Santi Andriani' ${ }^{1}$ Fita Rahmawati2*, Tri Murti Andayani2 \\ ${ }_{1}^{1}$ Program Pascasarjana Farmasi Klinik, Fakultas Farmasi, Universitas Gadjah Mada \\ 2 Departemen Farmakologi dan Farmasi Klinik, Fakultas Farmasi, Universitas Gadjah Mada \\ Corresponding author: Fita Rahmawati: Email: rahmawati_f@ugm.ac.id \\ Submitted: 12-08-2019 \\ Revised: 16-09-2019 \\ Accepted: 19-09-2019
}

\begin{abstract}
ABSTRAK
Pemberian obat dengan dosis sesuai pada pasien Chronic Kidney Disease (CKD ) penting dilakukan, salah satunya untuk memastikan luaran terapi obat yang optimal. Penelitian ini bertujuan mengetahui hubungan antara dose adjustment obat dan luaran terapi serta efisiensi biaya terapi obat dengan adanya dose adjustment pada pasien rawat inap dengan CKD. Jenis penelitian ini observasional dengan desain cross sectional. Sebanyak 200 rekam medis pasien rawat inap dengan CKD periode Januari - Desember 2017 di RSUD dr. Soeselo dan RSUD Suradadi Kabupaten Tegal dilibatkan dalam penelitian ini. Dose adjustment dihitung berdasarkan fungsi ginjal pasien, yang diestimasikan dengan laju filtrasi glomerular menggunakan formula Cockcroft-Gault. Hubungan antara dose adjustment obat dan luaran terapi menggunakan analisis Chi-square. Hasil penelitian menunjukkan terdapat 1882 obat yang diresepkan, 338 (17,93\%) obat memerlukan dose adjustment pada pasien CKD. Dari obat tersebut, 175 (51,78\%) obat diberikan dengan dose adjustment, sejumlah $118(67,43 \%)$ obat menghasilkan luaran terapi membaik , $23(15,52 \%)$ obat tidak membaik dan $34(19,43 \%)$ obat tidak dapat dievaluasi. Sedangkan dari 163 obat tanpa dose adjustment, 103 (63,19\%) obat menghasilkan luaran terapi membaik dan 40 (24,54\%) obat tidak membaik dan $20(12,27 \%)$ obat tidak dapat dievaluasi. Terdapat hubungan yang signifikan antara penyesuaian dosis obat dengan luaran terapi obat pada pasien rawat inap dengan CKD (OR 1,922, $95 \% \mathrm{CI}=1,119-3,548, \mathrm{p}=0,018)$. Penyesuaian dosis terbukti memberikan efisiensi biaya terapi obat pada penelitian ini sebesar Rp. 1.620.588,00.
\end{abstract}

Kata kunci: Chronic Kidney Disease; efisiensi biaya; luaran terapi; penyesuaian dosis

\section{ABSTRACT}

Appropriate dose of drugs for patients with Chronic Kidney Disease (CKD) is important to ensure optimal therapeutic outcome of drugs. The aims of this study were to determine the relationship between drug dose adjustment to clinical outcome and cost efficiency of drug therapy with dose adjustment in hospitalized patient with CKD. This study was a cross-sectional observational study. A total of 200 medical records of Hospitalized patient with CKD during the period January to December 2017 at RSUD dr. Soeselo and RSUD Suradadi, Tegal Regency were included in this study. Dose adjustment was calculated based on the patient's kidney function, which is estimated by the glomerular filtration rate using the Cockcroft-Gault formula. The relationship between drug dose adjustment to clinical outcome using Chi-square analysis. There were 1882 prescribed drugs, 338 (17,93\%) drugs required dose adjustment in patients with CKD. From 338 drugs that required a dose adjustment, dose of 175 (51,78\%) drugs were adjusted . From 175 drugs with dose adjustment, 118 (67,43\%) drugs provided improved clinical outcome, while $23(13,14 \%)$ drugs did not and $34(19,43 \%)$ drugs couldn't be evaluated. Whereas from 163 drugs without dose adjustment, $103(63,19 \%)$ provided improved clinical outcome, 40 (24,54\%) drugs did not and 20 $(12,27 \%)$ drugs could't be evaluated. There was a significant relationship between drug dose adjustment to clinical outcome in hospitalized patients with CKD (OR 1,922, 95\% CI = 1,119-3,548, $\mathrm{p}=0,018$ ). The cost efficiency of drugs with dose adjustment in this study was Rp. 1.620.588,00.

Keywords: Chronic Kidney Disease; cost efficiency; dose adjustment; therapeutic outcome 


\section{PENDAHULUAN}

Ginjal merupakan bagian tubuh yang kompleks baik secara struktur maupun fungsi. Fungsi ginjal dapat diukur melalui laju filtrasi glomerulus (GFR), yang dilakukan dengan pengukuran creatinine clearance berdasarkan nilai serum kreatinin. Penurunan nilai GFR dapat mengindikasikan adanya gangguan fungsi ginjal (Cartet-Farnier dkk., 2017). Salah satu gangguan fungsi ginjal adalah Chronic Kidney Disease (CKD), yang didefinisikan sebagai kerusakan ginjal dan/atau penurunan Glomerular Filtration Rate (GFR) kurang dari 60 $\mathrm{mL} / \mathrm{min} / 1,73 \mathrm{~m}^{3}$ selama minimal 3 bulan (Andrassy, 2013).

Pasien dengan gangguan fungsi ginjal seringkali memiliki parameter farmakokinetik, misalnya absorbsi obat, distribusi, ikatan protein, biotransformasi dan ekskresi ginjal, yang berbeda dengan pasien dengan fungsi ginjal normal. Sebagian besar obat dan metabolitnya dieliminasi melalui ginjal, sehingga dibutuhkan fungsi ginjal yang adekuat untuk menghindari toksisitas obat. Pasien juga dapat menunjukkan respon farmakodinamik yang berubah terhadap obat yang diberikan karena perubahan fisiologis dan biokimiawi yang terkait dengan insufisiensi ginjal (Y. dkk., 2009). Pemilihan dan dosis obat yang tepat untuk pasien dengan Chornic Kidney Disease (CKD) penting untuk menghindari efek obat yang tidak diinginkan dan memastikan luaran terapi yang optimal pada pasien. Dalam suatu penelitian di Penang General Hospital, Penang, upaya untuk mengurangi kesalahan dosis dapat menurunkan resiko terjadinya efek obat yang tidak diinginkan (Adverse Drug Events), menghasilkan luaran terapi yang optimal serta mengurangi biaya terapi obat dan biaya perawatan secara menyeluruh (Y. dkk., 2009).

Dalam penelitiannya, Matzke juga menyampaikan bahwa dose adjustment atau penyesuaian dosis merupakan upaya untuk mencapai pengobatan yang efektif dengan tujuan memaksimalkan luaran terapi dan meminimalkan risiko efek samping dan efisiensi biaya terapi obat (Y. dkk., 2009), (Matzke dkk., 2011). Dose Adjustment dapat dilakukan antara lain dengan mengurangi dosis obat dan interval pemberian obat tetap, menggunakan dosis normal dan memperpanjang interval obat atau memodifikasi dosis dan interval (Y. dkk., 2009). Penelitian ini bertujuan untuk mengetahui hubungan antara penyesuaian dosis dan luaran terapi obat serta efisiensi biaya terapi obat dengan adanya penyesuaian dosis obat pada pasien rawat inap dengan CKD.

\section{METODE}

\section{Rancangan Penelitian}

Penelitian ini bersifat observational dengan rancangan cross sectional. Tempat penelitian dilakukan di RSUD de Soeselo dan RSUD Suradadi Kabupaten Tegal dengan melihat rekam medis pasien bulan Januari Desember 2017.

\section{Subyek Penelitian}

Subyek penelitian ini antara lain pasien berusia $\geq 18$ tahun dengan rekam medis lengkap (data identifikasi pasien, berat badan, data kreatinin serum, hasil pemeriksaan laboratorium, data tanda dan gejala klinis pasien) dan pasien rawat inap dengan diagnosis CKD. Sejumlah 200 rekam medis dievaluasi pada penelitian ini. Berdasarkan perhitungan besaran sampel, jumlah minimal sampel yang diperlukan dalam penelitian ini adalah 97 rekam medis dengan $0=95 \%$. Penelitian ini layak secara etik berdasarkan surat persetujuan komite etik oleh Medical and Health Research Ethics Commitee (MHREC) Faculty of Medicne Gadjah Mada University-DR. Sardjito General Hospital dengan nomor Ref: KE/FK/0071/EC/2019

\section{Pengumpulan data}

Pengambilan sampel dilakukan dengan teknik convenience sampling. Data demografi pasien, regimen dosis obat, hasil pemeriksaan laboratorium, keluhan pasien, penyakit penyerta, hemodialisis diambil dari rekam medis pasien. Data harga obat diperoleh dari Instalasi Farmasi.

\section{Dose Adjustment Obat}

Fungsi ginjal pasien diestimasikan dengan laju filtrasi glomerular (eGFR) yang dilakukan dengan pengukuran creatinine clearance, berdasarkan nilai serum kreatinin, menggunakan formula Cockcroft-Gault. Selanjutnya dose adjustment obat dilakukan berdasarkan referensi The Renal Drug Handbook $5^{\text {th }}$ edition tahun 2018 dan Drug Information Handbook $26^{\text {th }}$ edition tahun 2017 yang disesuaikan dengan nilai creatinine clearance. 
Tabel I. Karakteristik Pasien Rawat Inap dengan Diagnosis CKD di RSUD dr. Soeselo dan RSUD Suradadi, Kabupaten Tegal

\begin{tabular}{|c|c|c|c|}
\hline Karakteristik & $\begin{array}{c}\text { Jumlah subjek } \\
(n=200)\end{array}$ & $\begin{array}{c}\text { Persentase } \\
\text { (\%) }\end{array}$ & Rata-rata \pm SD \\
\hline \multicolumn{4}{|l|}{ Jenis kelamin } \\
\hline Laki-laki & 94 & 47 & \\
\hline Wanita & 106 & 53 & \\
\hline Usia & & & $52,61 \pm 12,99$ \\
\hline 18 - 59 tahun & 142 & 71 & \\
\hline$\geq 60$ tahun & 58 & 29 & \\
\hline \multicolumn{4}{|l|}{ Tahapan CKD } \\
\hline CKD Tahap 3 & 7 & 3,5 & \\
\hline CKD Tahap 4 & 27 & 13,5 & \\
\hline CKD Tahap 5 & 166 & 83 & \\
\hline \multicolumn{4}{|c|}{ Penyakit Penyerta (Charlson Comorbidity Index) } \\
\hline Ringan ( $\leq 3$ poin) & 121 & 60,5 & \\
\hline Sedang ( $4-5$ poin) & 69 & 34,5 & \\
\hline Berat ( $\geq 6$ poin) & 10 & 5,0 & \\
\hline \multicolumn{4}{|l|}{ Hemodialisis } \\
\hline Menjalani Hemodialisis & 63 & 31,5 & \\
\hline Tidak Menjalani Hemodialisis & 137 & 68,5 & \\
\hline
\end{tabular}

\section{Luaran Terapi Obat}

Luaran terapi obat merupakan indikator yang menunjukkan keberhasilan terapi obat pada pasien. Luaran terapi obat dalam penelitian ini dibagi menjadi dua kelompok, yaitu membaik dan tidak membaik. Luaran terapi obat dikatakan membaik bila ditemukan perbaikan tanda-tanda vital pasien, tanda klinis pasien, hasil laboratorium dan atau keterangan membaik dari dokter yang merawat. Sebaliknya luaran terapi obat dikatakan tidak membaik bila tidak ditemukan perbaikan tanda-tanda vital pasien, tanda klinis pasien, hasil laboratorium dan atau keterangan membaik dari dokter yang merawat.

\section{Efisiensi Biaya Terapi Obat}

Efisiensi biaya terapi obat dihitung dari reduksi biaya obat jika dilakukan dose adjustment.

\section{Analisis statistik}

Data demografi pasien, tahapan CKD, jumlah penyakit penyerta, hemodialisis, jumlah item obat yang membutuhkan dose adjustment dianalisis secara deskripitif. Analisis hubungan antara dose adjustment obat dengan luaran terapi obat dilakukan menggunakan statistik Chi-square menggunakan program komputer SPSS

\section{HASIL DAN PEMBAHASAN \\ Karakteristik Pasien Rawat Inap dengan CKD}

Data karakteristik subyek penelitian pada pasien rawat inap CKD yang diteliti meliputi jenis kelamin, usia, tahapan CKD, penyakit penyerta dan hemodialisis yang tersaji pada tabel I. Data karakteristik pasien ini diperoleh dengan melihat rekam medis pasien.

Berdasarkan karakteristik pasien CKD, jumlah pasien perempuan sebanyak 106 (53\%) orang sedikit lebih tinggi dibandingkan dengan jumlah pasien laki-laki 96 (47\%) orang. Hal ini tidak sejalan dengan hasil Riskesdas 2018 Kemenkes RI yang menyebutkan bahwa jumlah pasien gagal ginjal didominasi pasien laki-laki sebesar 0,42\% (355.726 pasien), sementara jumlah pasien gagal ginjal perempuan sebesar 0,35\% (358.057 pasien(Kemenkes RI, 2013)). Perbedaan ini kemungkinan terjadi karena rasio jumlah penduduk Kabupaten Tegal tahun 2017 yang didominasi oleh jenis kelamin perempuan sebesar 50,30\% (721.004 orang), sedikit lebih banyak dibandingkan jumlah penduduk lakilaki sebesar 49,70 \% (712.511 orang) (BPS, 2018).

Menurut Kemenkes RI (2013), kelompok usia dibagi menjadi 2 yaitu dewasa dengan jarak usia 18-59 tahun dan lansia dengan usia $\geq 60$ Tahun. Hasil penelitian ini menunjukkan 
Tabel II. Data distribusi frekuensi penyakit penyerta pada pasien rawat inap dengan diagnosis CKD di RSUD dr. Soeselo dan RSUD Suradadi, Kabupaten Tegal

\begin{tabular}{lcc}
\hline Nama Penyakit Penyerta & Jumlah & Persentase (\%) \\
\hline Anemia & 111 & 26 \\
Hipertensi & 78 & 19 \\
Hypertensive Heart Disease & 46 & 11 \\
Diabetes Mellitus & 27 & 6 \\
Coronary Heart Disease & 21 & 5 \\
Ensefalopati Uremikum & 18 & 4 \\
Bronkopneumonia & 18 & 4 \\
Hiperkalemia & 10 & 2 \\
Penyakit Lain & 92 & 23 \\
\hline
\end{tabular}

prevalensi kelompok umur 18-59 tahun lebih mendominasi $(71 \%)$ dibandingkan kelompok usia >60 tahun (29\%). Hal ini sesuai dengan beberapa penelitian sebelumnya yang dilakukan oleh Y. Hassan (2009) yang menyebutkan bahwa usia rata-rata pasien CKD dalam penelitiannya berkisar 55 tahun (Y. dkk., 2009). Namun demikian hasil Riskesdas 2018 menyebutkan bahwa prevalensi penyakit ginjal kronis tertinggi pada pasien dengan usia 65-74 tahun sebanyak 8,23\% \% Perbedaan data ini kemungkinan karena sesuai data BPS, penduduk Kabupaten Tegal tahun 2017 didominasi oleh penduduk dengan usia $15-60$ tahun $(62,18 \%)$ (BPS, 2018).

Pasien yang mengalami CKD tahap 5 memiliki prevalensi tertinggi sebesar 83\% (166 pasien). Jumlah ini sejalan dengan penelitian lain yang menyatakan bahwa pasien CKD tahap 5 memiliki prevalensi tertinggi, yaitu sebesar $38,6 \%$ pada penelitian yang dilakukan oleh Hammad (2016) dan 88,7\% pada penelitian yang dilakukan oleh Hassan (2009). Prevalensi ini juga sejalan dengan data yang disampaikan IRR 2017 yang menyatakan bahwa jumlah pasien hemodialisis semakin meningkat, dimana prevalensi terbesar adalah pasien dengan CKD tahap 5 (Indonesian dkk., 2017).

Berdasarkan komorbid yang dihitung dengan metode Charlson Comorbidity Index (CCI) dapat dilihat bahwa pasien dengan penyakit penyerta ringan $(\leq 3)$ sebanyak 121 pasien (60,5\%), sedang (4-5) sebanyak 69 pasien $(34,5 \%)$ dan berat $(\geq 6)$ sebanyak 10 pasien (5\%). Hasil ini sejalan dengan penelitian Azalea (2016) yang menyebutkan bahwa pasien CKD dengan penyakit penyerta kategori ringan memiliki prevalensi tertinggi sebesar 53,2\% (Azalea dan Andayani, 2016). Jenis penyakit yang banyak dijumpai adalah anemia (26\%), hipertensi (19\%), hypertensive heart disease (11\%), dan diabetes mellitus (6\%). Data penyakit penyerta selengkapnya dapat dilihat pada tabel II.

Hemodialisis merupakan proses terapi pengganti ginjal dengan menggunakan selaput membran semi permeabel (dialiser), yang berfungsi seperti nefron sehingga dapat mengeluarkan produk sisa metabolisme dan mengoreksi gangguan keseimbangan cairan dan elektrolit pada pasien gagal ginjal (Hutagaol, 2017). Tercatat $31,5 \%$ (63 pasien) dalam penelitian ini yang menjalani hemodialisis. Jumlah ini tidak sebanding dengan prevalensi pasien CKD tahap 5 sebesar 83\% (166 pasien). Hal ini juga tidak sejalan dengan data yang disampaikan IRR 2017 yang menyatakan bahwa jumlah pasien hemodialisis semakin meningkat, dimana prevalensi terbesar adalah pasien dengan CKD tahap 5 (Indonesian dkk., 2017). Menurut keterangan perawat, hal tersebut terjadi karena sebagian pasien menolak untuk menjalani hemodialisis.

\section{Dose Adjustment Obat}

Dari 200 pasien, sebanyak 192 pasien mendapatkan obat yang membutuhkan dose adjustment. Sejumlah 1882 obat diresepkan, dimana 338 (17,96\%) obat di antaranya membutuhkan dose adjustment pada pasien CKD, sedangkan sisanya tidak membutuhkan. Obat-obat yang paling banyak membutuhkan dose adjustment antara lain ranitidin (19,70\%), ketorolak $(13,33 \%)$ dan sukralfat $(11,21 \%)$.

\section{Ranitidin}

Ranitidin merupakan obat golongan antagonis reseptor $\mathrm{H} 2$ (H2RAs) yang direkomendasikan untuk dilakukan penyesuaian dosis saat diberikan pada pasien 
dengan penurunan klirens kreatinin (GFR). Sesuai referensi, untuk pasien dengan $\mathrm{CrCl}<10$ $\mathrm{ml} / \mathrm{min} / 1,73 \mathrm{~m}^{2}$, dosis ranitidin yang direkomendasikan sebesar $50-100 \%$ dosis normal untuk pemakaian oral dan $50 \mathrm{mg}$ tiap 12 jam untuk pemakaian intravena (Ashley, 2018). Pada penelitian ini, terdapat 70 kali peresepan ranitidin, dimana 97,10\% (67 kali pemberian ranitidin) diantaranya sudah diberikan dengan dose adjustment. Penyesuaian dosis ranitidin perlu dilakukan pada pasien CKD. Dalam suatu penelitian disebutkan bahwa pada pasien dengan penurunan GFR, terjadi peningkatan signifikan pada AUC dan waktu paruh eliminasi $\left(t_{1 / 2}\right)$ dari konsentrasi obat H2RAs dalam serum $(\mathrm{P}<0,001)$. Dibandingkan dengan GFR $>80 \mathrm{ml} /$ menit / 1,73m², AUC ranitidine meningkat $200 \%$ pada GFR $30 \mathrm{ml} / \mathrm{min} / 1,73 \mathrm{~m} 2$, dan $300 \%$ pada GFR $20 \mathrm{ml} /$ menit / 1,73m². Peningkatan AUC ini menjadi dasar diperlukannya penyesuaian dosis ranitidin karena berhubungan dengan potensi munculnya efek samping obat yang tidak diinginkan. Dalam penelitian yang sama disebutkan juga bahwa efek perlindungan H2RA terhadap saluran pencernaan tidak berbeda signifikan baik diberikan dengan dosis yang telah disesuaikan maupun dengan dosis yang belum disesuaikan (Manlucu dkk., 2005). Sementara penelitian lain menyebutkan bahwa waktu paruh ranitidin pada pasien dengan gangguan fungsi ginjal meningkat menjadi 7,3 jam yaitu setara dengan 2,4 kali waktu paruh ranitidin pada pasien dengan fungsi ginjal normal (Hammad dkk., 2016). Hal ini menunjukkan terjadinya penurunan eliminasi ranitidin pada pasien dengan gangguan fungsi ginjal, yang berisiko meningkatkan efek samping obat yang tidak diharapkan. (Y. dkk., 2009).

\section{Ketorolak}

Ketorolak termasuk obat golongan NSAIDs yang bekerja menghambat prostaglandin, dimana obat-obat tersebut dilaporkan menyebabkan nefrotoksisitas. Terjadi peningkatan 2,5 kali lipat risiko CKD pada penggunaan ketorolak jangka pendek, yang menyiratkan bahwa penggunaan NSAIDs potensi tinggi ini dapat memfasilitasi progresivitas penyakit CKD pada pasien (Ingrasciotta dkk., 2015). Ketorolak dan metabolitnya diekskresikan terutama oleh ginjal. Menurut referensi, dosis ketorolak yang direkomendasikan untuk pasien dengan $\mathrm{CrCl}$ 20-50 ml/min/1,73 $\mathrm{m}^{2}$ sebesar $15 \mathrm{mg}$ tiap 6 jam atau maksimum $60 \mathrm{mg} /$ hari, sedangkan untuk pasien dengan $\mathrm{CrCl}<20 \mathrm{ml} / \mathrm{min} / 1,73 \mathrm{~m}^{2}$, direkomendasikan untuk menghindari penggunaan ketorolak (Ashley, 2018). Pada penelitian ini, ketorolak diresepkan sebanyak 48 kali, dimana 95,83\% (46 kali peresepan) di antaranya tidak dilakukan dose adjustment. Penggunaan ketorolak tanpa penyesuaian dosis pada pasien CKD dapat meningkatkan risiko efek obat yang tidak diinginkan antara lain perdarahan pada saluran pencernaan, peningkatan frekuensi kemih, oliguria, gagal ginjal akut, hiponatremi, hiperkalemi serta meningkatkan ureum dan kreatinin serum (Ashley, 2018). Efek samping obat yang tidak diinginkan tidak ditemukan pada pasien yang mendapatkan ketorolak dalam penelitian ini.

\section{Sukralfat}

Pada pasien dengan gangguan fungsi ginjal, sukralfat harus digunakan dengan hatihati karena adanya kandungan aluminium yang terabsorbsi dan terakumulasi. Pada pasien CKD dengan hemodialisis, sukralfat hanya boleh digunakan dalam periode singkat karena aluminium yang terabsorbsi dapat terikat dengan protein plasma dan tidak dapat terdialisis (Ashley, 2018). Akumulasi aluminium dan toksisitasnya telah dilaporkan pada pasien dengan gangguan fungsi ginjal yang menggunakan sukralfat. Risiko toksisitas ini kemungkinan merupakan komplikasi penggunaan sukralfat jangka panjang. Oleh karena itu, pasien dengan gagal ginjal atau insufisiensi ginjal yang menjalani terapi sukralfat jangka panjang harus mendapatkan pengawasan terkait tanda-tanda toksisitas aluminium (Hemstreet, 2001). Pada penelitian ini, ditemukan sebanyak 36 kali peresepan sukralfat suspensi dimana dose adjustment obat tidak dilakukan pada tiap peresepan. Efek samping sukralfat seperti konstipasi dan insomnia ditemukan pada beberapa pasien.

\section{Levofloxacin}

Levofloxacin merupakan antibiotik golongan floroquinolon generasi ke 3 . Farmakokinetik obat golongan ini menunjukkan adanya eliminasi obat yang signifikan melalui ginjal. Pada pasien dengan CKD, proses eliminasi tersebut dapat berkurang sehingga memungkinkan terjadinya akumulasi obat 


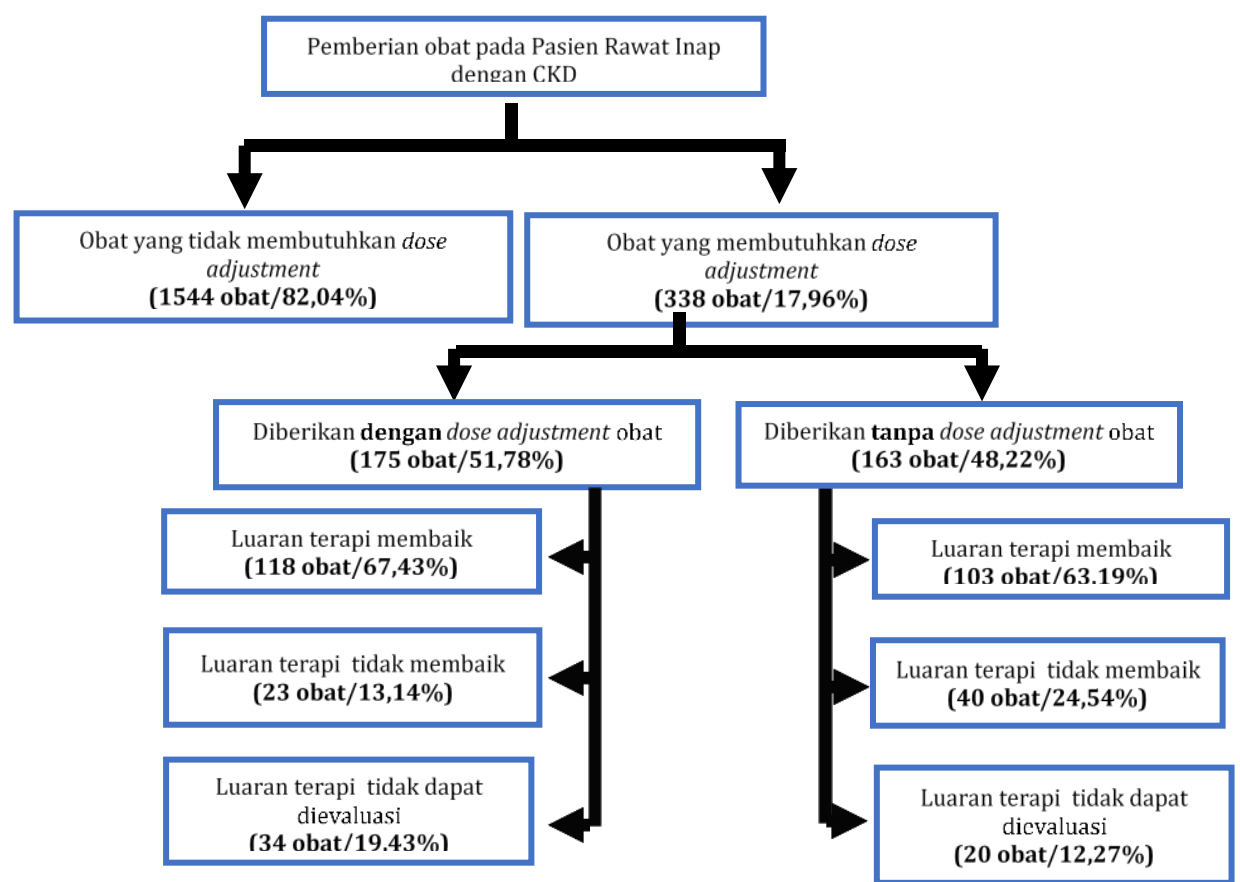

Gambar 1. Skema Luaran Terapi Obat Pada Pasien Rawat Inap Dengan Diagnosis CKD Di RSUD Dr Soeselo Dan RSUD Suradadi, Kabupaten Tegal

Tabel III. Hubungan Dose Adjustment Obat Dan Luaran Terapi Pasien Rawat Inap Dengan Diagnosis CKD di RSUD dr Soeselo dan RSUD Suradadi, Kabupaten Tegal

\begin{tabular}{|c|c|c|c|c|c|}
\hline \multirow[b]{2}{*}{ Dose Adjustment } & \multirow{2}{*}{$\begin{array}{c}\text { Jumlah } \\
\text { Obat }\end{array}$} & \multicolumn{2}{|c|}{ Luaran Terapi } & \multirow[b]{2}{*}{ OR $(95 \% C I)$} & \multirow[b]{2}{*}{ Nilai P } \\
\hline & & Membaik & $\begin{array}{c}\text { Tidak } \\
\text { Membaik }\end{array}$ & & \\
\hline Obat dengan Dose Adjustment & 141 & 118 & 23 & $1,992(1,199-$ & 0,018 \\
\hline Obat tanpa Dose Adjustment & 143 & 103 & 40 & $3,548)$ & \\
\hline Jumlah Total Obat & 284 & & & & \\
\hline
\end{tabular}

Keterangan : Analisis Chi-square; *signifikan secara statistik $(\mathrm{P}<0,05)$; Odds Ratio (OR); Confidence Interval (CI)

dalam darah yang dapat memicu terjadinya efek samping obat yang tidak diinginkan. Sesuai referensi, untuk pasien dengan $\mathrm{CrCl}$ 20-50 $\mathrm{ml} / \mathrm{min} / 1,73 \quad \mathrm{~m}^{2}$, dosis awal yang direkomendasikan sebesar 250-500 mg dilanjutkan dengan $125 \mathrm{mg}-250 \mathrm{mg}$ tiap 12-24 jam. Sedangkan untuk pasien dengan $\mathrm{CrCl}$ 10-20 $\mathrm{ml} / \mathrm{min} / 1,73 \quad \mathrm{~m}^{2}$, dosis awal yang direkomendasikan sebesar 250-500 mg dilanjutkan dengan $125 \mathrm{mg}$ tiap 12-48 jam. Sementara itu, untuk pasien dengan $\mathrm{CrCl}$ 10-20 $\mathrm{ml} / \mathrm{min} / 1,73 \quad \mathrm{~m}^{2}$, dosis awal yang direkomendasikan sebesar 250-500 mg dilanjutkan dengan $125 \mathrm{mg}$ tiap 24-48 jam (Ashley, 2018). Pada penelitian ini, levofloxacin diresepkan sebanyak 24 kali, dimana 95,83\%
(23 kali peresepan) di antaranya diberikan dengan dose adjustment.

\section{Luaran Terapi Obat}

Luaran terapi obat dalam penelitian ini dibagi menjadi dua kelompok, yaitu membaik dan tidak membaik. Dari 175 obat dengan dose adjustment, 118 (67,43\%) obat menghasilkan luaran terapi membaik, 23 (13,14\%) obat menghasilkan luaran terapi tidak membaik dan 34 (19,43\%) obat tidak dapat dievaluasi luaran terapinya. Sedangkan dari 163 obat tanpa dose adjustment, 103 (63,19\%) obat menghasilkan luaran terapi membaik, 40 (24,54\%) obat menghasilkan luaran terapi tidak membaik dan $20(12,27 \%)$ obat tidak dapat dievaluasi luaran 
terapinya. Luaran terapi membaik dari obat tanpa dose adjustment ini kemungkinan disebabkan karena adanya peningkatan dosis obat dengan rentang 12,5 - 650\% dari dosis yang direkomendasikan. Peningkatan dosis obat ini berisiko meningkatkan terjadinya efek obat yang tidak diinginkan (Tesfaye dkk., 2017). Data luaran terapi obat dapat dilihat selengkapnya pada Gambar 1.

\section{Hubungan Antara Dose Adjustment Obat Dengan Luaran Terapi Obat Pada Pasien Rawat Inap Dengan CKD}

Berdasarkan tabel III diketahui bahwa terdapat hubungan antara dose adjustment obat terhadap luaran terapi obat pada pasien rawat inap dengan CKD dengan nilai $\mathrm{p}=0,018$ (OR $1,992,95 \% \mathrm{CI}=1,119-3,548, \mathrm{p}=0,018$ ), dimana pasien yang mendapatkan obat dengan dose adjustment memiliki ketercapaian luaran terapi obat 1,992 kali lebih tinggi dibandingkan pasien yang mendapatkan obat tanpa dose adjustment. Hasil penelitian ini sejalan dengan penelitian lain yang menyatakan bahwa terdapat hubungan antara dosis obat antihipertensi dan respon terapi pada pasien hipertensi dengan gangguan fungsi ginjal (Wang dkk., 2015). Dalam suatu penelitian juga disebutkan bahwa terdapat hubungan antara rasionalitas pendosisan terhadap outcome terapi pneumonia pada pasien dengan gangguan fungsi ginjal (Ilma, 2017).

\section{Efisiensi Biaya Terapi Obat}

Efisiensi (penghematan) biaya didapatkan dari selisih pada perhitungan jumlah biaya obat riil (sebenarnya) yang didapatkan pasien dikurangi dengan jumlah biaya obat dengan dose adjustment. Perkiraan penghematan biaya obat yang diperoleh dari hasil dose adjustment obat dalam penelitian ini sebesar Rp. 1.620.588,00 (Satu Juta Enam Ratus Dua Puluh Ribu Lima Ratus Delapan Puluh Delapan Rupiah). Hasil perolehan ini hanya terbatas pada efisiensi biaya terapi obat, dan tidak termasuk total kemungkinan efisiensi biaya. Penghematan dalam biaya administrasi, seperti bahan dan waktu perawatan serta efisiensi biaya karena penghindaran dari munculnya efek samping obat tidak dihitung. Secara teoritis, dosis obat yang berlebihan berhubungan dengan meningkatnya toksisitas dan efek samping obat (Hassan dkk., 2009). Penyesuaian dosis obat pada pasien CKD dapat menghemat biaya terapi obat dan memperkecil efek samping obat (Falconnier dkk., 2001). Hal senada juga disampaikan dalam penelitian lain yaitu bahwa adjustment dosis merupakan upaya efisiensi biaya pengobatan pada pasien dengan gangguan ginjal (Dian, 2016).

\section{KESIMPULAN}

Hasil penelitian memberikan simpulan terdapat hubungan yang signifikan antara penyesuaian dosis obat dengan luaran terapi obat pada pasien rawat inap dengan CKD (OR 1,922, 95\% CI $=1,119-3,548, \quad \mathrm{p}=0,018)$. Penyesuaian dosis terbukti memberikan efisiensi biaya terapi obat pada penelitian ini sebesar Rp. 1.620.588,00.

\section{UCAPAN TERIMAKASIH}

PPSDM Kementrian Kesehatan yang telah memberikan dana dan RSUD dr. Soeselo dan RSUD Suradadi Kabupaten Tegal sebagai tempat penelitian. Seluruh penulis tidak memiliki konflik interest terhadap instansi yang terlibat dalam penelitian.

\section{DAFTAR PUSTAKA}

Andrassy, K.M., 2013. Comments on 'KDIGO 2012 clinical practice guideline for the evaluation and management of chronic kidney disease.' Kidney International, 84: 622-623.

Ashley, C., 2018. The Renal Drug Handbook, The Renal Drug Handbook.

Azalea, M. dan Andayani, T.M., 2016. Analisis Biaya Pengobatan Penyakit Ginjal Kronis Rawat Inap dengan Hemodialisis di Rumah Sakit. Jurnal Manajemen dan Pelayanan Farmasi, 6: .

BPS, 2018a. 'Jumlah Penduduk dan Rasio Jenis Kelamin',.URL:https://tegalkab.bps.go.id /statictable/2015/01/22/44/jumlahpenduduk-dan-rasio-jenis-kelaminmenurut-kecamatan-di-kabupaten-tegaltahun-2017.html (diakses tanggal 14/6/2019).

BPS, 2018b. 'Jumlah Penduduk Menurut Usia', URL:https://tegalkab.bps.go.id/statictab le/2015/01/22/45/jumlah-pendudukmenurut-kelompok-umur-dan-jeniskelamin-di-kabupaten-tegal-tahun2017.html (diakses tanggal 17/6/2019).

Cartet-Farnier, E., Goutelle-Audibert, L., Maire, P., De la Gastine, B., dan Goutelle, S., 2017. Implications of using the MDRD or CKD- 
EPI equation instead of the CockcroftGault equation for estimating renal function and drug dosage adjustment in elderly patients. Fundamental and Clinical Pharmacology, 31: 110-119.

Dian, 2016. Adjustment Dosis Sebagai Upaya Efisiensi Biaya Pengobatan pada Pasien dengan Gangguan Ginjal di Rumah Sakit UGM.

Falconnier, A.D., Haefeli, W.E., Schoenenberger, R.A., Surber, C., dan Martin-Facklam, M., 2001. Drug Dosage in Patients with Renal Failure Optimized by Immediate Concurrent Feedback. J Gen Intern Med, 369-375

Hammad, M.A., Alakhali, K.M., Khamis, A.A., dan Elsayed, T., 2016. Evaluation of Drug Dosing in Renal Failure.pdf.

Hemstreet, B.A., 2001. Use of Sucralfate in Renal Failure. The Annals of Pharmacotherapy, 35: 5.

Hutagaol, E.V., 2017. Peningkatan Kualitas Hidup Pada Penderita Gagal Ginjal Kronik Yang Menjalani Terapi Hemodialisa Melalui Psychological Intervention di Unit Hemodialisa RS Royal Prima Medan Tahun 2016 2: 18.

Ilma, D.L., 2017. Evaluasi Pendosisan Seftizidim pada Pasien Pneumonia dengan Gangguan Fungsi Ginjal.

Indonesian, P., Registry, R., dan Course, H., 2017. Indonesian Renal Registry.

Ingrasciotta, Y., Sultana, J., Giorgianni, F., Fontana, A., Santangelo, A., Tari, D.U., dkk., 2015. Association of Individual NonSteroidal Anti-Inflammatory Drugs and Chronic Kidney Disease: A PopulationBased Case Control Study. PLOS ONE, 10:. Manlucu, J., Tonelli, M., Ray, J.G., Papaioannou, A., Youssef, G., Thiessen-Philbrook, H.R., dkk., 2005. Dose-reducing $\mathrm{H} 2$ receptor antagonists in the presence of low glomerular filtration rate: a systematic review of the evidence. Nephrology Dialysis Transplantation, 20: 2376-2384.

Matzke, G.R., Aronoff, G.R., Atkinson, A.J., Bennett, W.M., Decker, B.S., Eckardt, K.-U., dkk., 2011. Drug dosing consideration in patients with acute and chronic kidney disease-a clinical update from Kidney Disease: Improving Global Outcomes (KDIGO). Kidney international, 80: 112237.

Tesfaye, W.H., Castelino, R.L., Wimmer, B.C., dan Zaidi, S.T.R., 2017. Inappropriate prescribing in chronic kidney disease: A systematic review of prevalence, associated clinical outcomes and impact of interventions. International Journal of Clinical Practice, 71: 1-16.

Wang, Q., Xie, D., Xu, Xin, Qin, X., Tang, G., Wang, B., dkk., 2015. Blood pressure and renal function decline. Journal of Hypertension, 33: 136-143.

Y., H., R.J., A.-R., N.A., A., dan R., G., 2009. Impact of a renal drug dosing service on dose adjustment in hospitalized patients with chronic kidney disease. Annals of Pharmacotherapy, 43: 1598-1605. 